\title{
Arthroscopic Follow-Up After Rupture of the Cranial Cruciateligament
}

\author{
Cleuza Maria de Faria Rezende, \\ Eliane Gonçalves de Melo and Natalie Ferreira Borges \\ Escola de Veterinária - UFMG, \\ Brazil
}

\section{Introduction}

The femoro-patellar-tibial joint is one of the most complex, with different structures that, altogether, keep the joint stability and functionality (Cook, 2010; de Rooster et al., 2010, Pozzi \& Kim, 2010). Due to its big functional demand, the cranial cruciate ligament (CrCL) is the structure most frequently injured. The rupture of this ligament is of the most common causes of lameness in the dog and the resulting instability leads to the development of degenerative joint disease (DJD). Still today, the search for the ideal technique to treat CrCL rupture, with joint stabilization and prevention or minimization of DJD, persists. However, would joint stabilization be the only factor to be considered for the treatment of CrCL rupture and its sequels? Won't the effects of instability on the other structures deserve more investigation? Would the inflammatory response mediators be responsible for the looseness of the intra-articular graft or is it exclusively due to improper fixation or inadequate postoperatory?

According to literature, the joint degeneration process starts as soon as seven days after CrCL rupture and, at Day 21, signals suggesting osteoarthritis can be radiographically examined. In arthroscopic evaluation, however, lesions are already significant and characteristic in this period.

Arthroscopy is a minimally invasive exam, with minimal morbidity, which allows complete visualization of structures with magnification of images and precise diagnosis of the articular condition in its natural environment. The minimal morbidity enables periodic joint evaluations (Van Ryssen \& Van Bree, 1998; Hulse et al., 2010; Goldhammer et al., 2010), what permits to monitor the lesion (Borges, 2006; Bleedorn et al., 2011) and the treatment evolution (Case et al., 2008), allowing the articular function prognosis (Ljungvall \& Ronéus, 2011).

Arthroscopy can be employed for evaluating and defining the DJD staging. It gives the surgeon a better understanding of the joint degeneration process, the most prevailing condition among all diseases in the dog.

The arthroscopy had a significant impact especially in our clinical practice in what concerns diagnosis and treatment of articular alterations in the dog. Non-specific arthritis, 
hemarthrosis, meniscus lesions, ligament partial ruptures, femoral condyle osteochondrosis, and presence of loose cartilaginous bodies not diagnosed by the radiographic exam are examples of clinical situations that nowadays are promptly diagnosed and treated through arthroscopy.

The arthroscopic monitoring of the femoro-patellar-tibial joint after CrCL rupture changed the procedures by which such condition is treated in our routine, and its stabilization began to be considered as a condition that must be treated the most precociously possible and through arthroscopy. The main challenge is the development of efficient therapies for the osteoarthritis control. The association of articular stabilization with cell therapy (stem cells, growth factors) is one of the alternatives under study at the moment. The purpose of this chapter is, in the meanwhile, presenting the articular findings, under arthroscopic vision, 21 days after arthroscope-guided CrCL rupture, taking as reference the parameters found in the arthroscopic exam right before rupture.

The rupture of the cranial cruciate ligament (CrCL) is one of the most frequent orthopedic affections in the dog (Johnston, 1997; Beale \& Hulse, 2010; Van Bree et al., 2010). After rupture, the $\mathrm{CrCL}$ does not regenerate, leading to lost of joint stability. The resulting instability leads to the development of degenerative joint disease (DJD) ( Innes, 2010), and treatment is still challenging. The unavoidable DJD progression (Vasseur \& Berry, 1992; Lazar et al., 2005) is caused by enzymatic degradation of the articular cartilage (Bennett \& May, 1997). As the alterations in the cartilage progress, reduction in the content of proteoglycans, hyalunoric acid, and collagen (in minor proportion) occur due to the action of catabolic enzymes released by the DJD. Once the cartilaginous lesion is installed, the subchondral bone is exposed to the synovial fluid and, when subjected to abnormal pressures and tensions, reacts forming osteophytes and subchondral sclerosis (Johnston, 1997). Periarticular osteophytes indicate articular instability and are one of the most evident radiographic signs of DJD (Schrader, 1995; Innes et al., 2004). Osteophytes are bone projections located at the peripheral region of the joint, most frequently at the osseous insertion of the synovial membrane, the perichondrium, and the periosteum, though it may occur at the central region of the joint (Johnston, 1997). As the DJD evolves, after CrCL rupture, formation of osteophytes occurs first at the osteochondral margin of the lateral and medial trochlear ridges, then at the proximal region of the tibia and the proximal and distal borders of the patella (Lewis et al., 1987; Moore \& Read, 1996). Some studies attribute to the synovitis and the consequent release of inflammatory mediators by the synoviocytes the triggering factors for DJD (Lipowitz et al., 1985;). In DJD, the synovial villi are hypertrophied, with augmented mature and immature collagen in the subsynovial tissue (Jonhston, 1997). McIlwraith \& Fessler (1978) classified morphologically the villi in filamentous, thin, interlaced, short, and in the shapes of polyp, staff, fringe, bush, fan, and cauliflower. In normal joints, the thin polyp-shaped, and the short, rounded, membranous and staff-shaped villi are commonly observed (McIlwraith \& Fessler, 1978; Kurosaka et al., 1991), while bigger and reddish villi, with petechial hemorrhages, and in the shapes of fan, cauliflower, fringe and bush are frequently found in joints with synovitis (Mcllwraith \& Fessler, 1978). The follow-up of the degenerative process evolution, as well as its treatment response, is constantly challenging. Among the methods routinely used in DJD diagnosis are the clinical evaluation (which is subjective) and the radiographic and ultrasonographic examination (which rely on the evaluator's experience). The arthroscopy is another 
diagnostic method that, despite being an invasive procedure and requiring anesthesia, it allows direct and magnified evaluation of the articular structures, and enables serial evaluations, once tissue invasion and morbidity are minimal (Van Ryssen \& Van Bree, 1998; Frizziero \& Ronchetti, 2002; Arias et al., 2003; Beale et al., 2003; Melo et al., 2003; Borges, 2006; Rezende et al., 2006; Hulse, et al., 2010; Bleedorn et al., 2011). In CrCL rupture, arthroscopy offers more than a precise diagnosis of the affection, it allows evaluation through magnified visualization of degenerative alterations of the joint such as fibrillation, cartilage erosion, synovial membrane proliferation, and neovascularization, osteophytes formation, besides detecting lesions in the menisci (Siemering \& Eilert, 1986; Adamiak, 2002; Borges, 2006; Case et al., 2008; Goldhammer et al., 2010; Hulse et al., 2010; Bleedorn et al., 2011.

Arthroscopy in dogs, initially employed for diagnostic purpose, has become a surgical alternative to many articular affections (Rochat, 2001) and has revolutionized the treatment of joint disease in human beings and animals (Beale \& Hulse, 2010). The magnifying of the structures allows the surgeon to recognize and treat lesions that could not be distinguished through arthrotomy (Van Ryssen \& Van Bree, 1998; Sams, 2000; Borges, 2006; Beale \& Hulse, 2010; Hulse et al, 2010; Bleedorn et al., 2011 ).

\section{Materials and methods}

This study was submitted to and approved by the UFMG committee for ethics in research, under protocol number 14/02.

Eighteen mixed breed, adult healthy dogs (9 males and 9 females), with 18 to $25 \mathrm{~kg}$ of body mass were used in this work. The animals were sheltered in individual cages and fed with commercial pet food and water ad libitum. Bilateral radiographic examination of the stifle joint was performed in craniocaudal and mediolateral incidences to confirm the radiographic normality of these joints in both hind limbs. Blood samples were collected for serum biochemical analysis, hemogram, and coagulogram. After 15 days of adaptation period, the first arthroscopy was performed to articular evaluation and CrCL section, and the second, for articular evaluation 21 days later. The animals were premedicated with atropine sulfate $(0.044 \mathrm{mg} / \mathrm{kg})$, subcutaneously, and xylazine chlorhydrate $(1 \mathrm{mg} / \mathrm{kg})$, intramuscularly. Anesthesia was induced with sodium thiopental $(12.5 \mathrm{mg} / \mathrm{kg})$, intravenously, and maintained with isoflurane in semi-open circuit. Antibiotic prophylaxis was performed with cefalotin $(30 \mathrm{mg} / \mathrm{kg}$ ), intravenously, 30 minutes before surgery. All animals received tramadol chlorhydrate $(2 \mathrm{mg} / \mathrm{kg})$, intramuscularly, in the immediate postoperative period and during 24 hours for pain management.

The animals were submitted to arthroscopic evaluation and subsequent CrCL section. The animals were prepared for aseptic surgery and positioned in dorsal recumbence over a metal gutter. Synovial fluid was collected in heparinized syringe and the joint cavity was distended with 10 to $15 \mathrm{ml}$ of Ringer's lactate solution thereafter. A $5 \mathrm{~mm}$ cutaneous incision was performed in the lateral parapatellar region, and the articular capsule was incisioned with a scalpel blade No. 11 for introducing the arthroscopic sheath guided by atraumatic trocar. The irrigation system was attached to the arthroscopic sheath while the atraumatic trocar was removed and replaced by a $2.7 \mathrm{~mm}, 30^{\circ}$ arthroscope, connected to the camera. Arthroscopic evaluation was conducted based on the articular compartments, as suggested by Person (1985). Articular structures were inspected: the lateral compartment with 
visualization of the synovial membrane, the lateral femur condyle, the long digital extensor tendon, the intercondylar fossa, the tibial plateau, the menisci, the intermeniscal and cruciate ligaments, the medial compartment, the medial femur condyle, the femoropatellar joint (articular surfaces of femur and patella, trochlear ridges), and the suprapatellar pouch. A second cutaneous and capsular incision was performed in the medial parapatellar region for introducing the arthroscopic scissor, as mentioned above. The CrCL was sectioned, remaining the intra-articular stumps. The $\mathrm{CrCL}$ section was confirmed by direct visualization by arthroscopy, and by the test of cranially dislocating the tibia in relation to the femur. The animals were kept in individual $4.5 \mathrm{~m}^{2}$ cages, for 21 days, and, after that period, submitted to new arthroscopic examination. Synovial fluid was collected, and the joint cavity was distented as described above. The intra-articular structures were systematically evaluated, as previously described, and the alterations found in the soft and in the hard tissues were documented. The images were analyzed based on the arthroscopic findings on Day 0, when the first arthroscopy was performed followed by the CrCL rupture, and at Day 21, when a new arthroscopy was conducted for evaluating the articular lesions. The structures were also individually evaluated, and abnormalities were registered. According to their quantity and aspect, villi were classified (Tab.1) from 1 to 4; grade 1 represented absence of lesion and 4, severe lesion. The villi were also morphologically classified as: filamentous, thin, interlaced, short, and as polyp, staff, fringe, bush, fan, and cauliflower shapes. In addition, they were categorized in respect to their localization: lateral and medial compartments, patellar ligament, and patellar tendon. The presence or absence of intra-articular fibrous cords was taken into account. Additionally, the articular cartilage was evaluated by area: patella, suprapatellar pouch, trochlear surface, intercondylar fossa, medial and lateral femur condyles, trochlear ridges of the femur, and surface of the tibia condyles. Likewise, the presence of osteophytes was classified according to the scores in Table 2.

Villi of the synovial membrane

$\begin{array}{ll}\text { Score } & \text { Description } \\ 1 & \text { Absent. } \\ 2 & \text { Mild: thin, filamentous, and short villi; white or rosy. } \\ 3 & \begin{array}{l}\text { Moderate: thin, filamentous, short, in the shapes of polyp, fan, bush, and staff } \\ \text { villi; reddish. }\end{array} \\ & \begin{array}{l}\text { Severe: numerous villi, dense in the shapes of cauliflower, fringe, located mainly } \\ \text { at the lateral and medial compartments; with hemorrhagic aspect and reddish } \\ \text { color. }\end{array}\end{array}$

Vascularization of the synovial membrane

$\begin{array}{ll}\text { Score } & \text { Description } \\ 1 & \text { Absent. } \\ 2 & \text { Mild: discrete presence of ingurgitated vessel in up to two regions. } \\ 3 & \begin{array}{l}\text { Moderate: vascularization, apparent hyperemia at the lateral and medial } \\ \text { compartments, cruciate ligaments, and menisci. }\end{array} \\ 4 & \begin{array}{l}\text { Severe: hypervascularization, hyperemia of the lateral and medial } \\ \text { compartments, menisci, and ligaments; articular hemorrhage. }\end{array}\end{array}$

Table 1. Scores system for the synovial membrane characteristics evaluated by stifle joint arthroscopy on Days 0 and 21 after section of the cranial cruciate ligament (CrCL). 


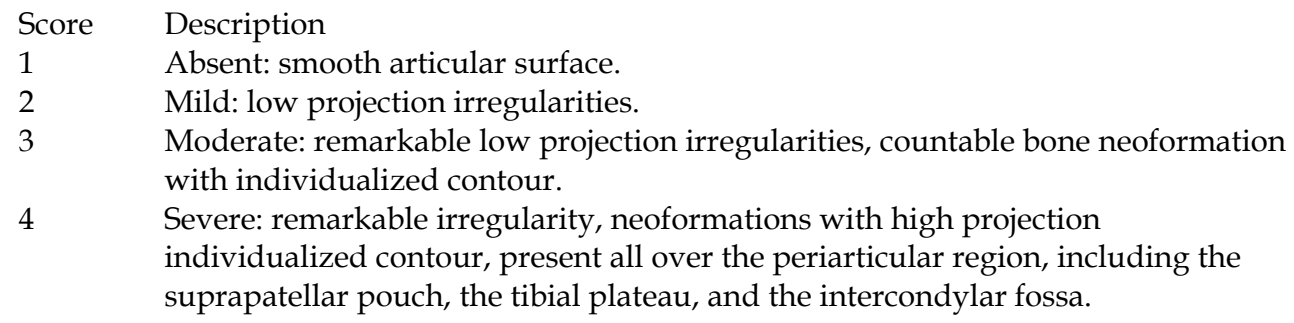

Table 2. Score system for the presence of osteophytes evaluated by stifle joint arthroscopy on Days 0 and 21 after section of the cranial cruciate ligament (CrCL).

The lateral and medial menisci were evaluated according to the presence or absence of lesion. For the cruciate ligaments, the presence or absence of alterations was determined, according to neovascularization, looseness, and fiber rupture. The long digital extensor tendon was evaluated according to the presence or absence of neovascularization and villi at the insertion of the femur condyle. The variables of this study are the lesions that might have arisen or evolved, after the ligament rupture, evaluated on Day 21 by arthroscopy. The Wilcoxon test was employed for paired samples for all variables (lesions), except osteophytes, for which a unilateral test was used. For comparisons, significance was set at $\mathrm{P}<0.05$.

\section{Results and discussion}

The arthroscopic examination was possible in both evaluation moments, and, as described by Person (1985), systematic examination of the joint allowed the ordering of the results (Tables 3 and 4). All structures that were visualized on Day 0 were also seen on Day 21, when it was possible to detect, in $100 \%$ of the joints, alterations in relation to Day 0 , fact that was expected given the joint instability, however, statistical significance was noticed in $83.3 \%$ (Table 5). The parapatellar approach was adequate for evaluating all the articular structures or regions in this study, as well as for sectioning the CrCL. The positioning of the animal allowed flexion, extension, varus and valgus movements, and rotation of the joint during the procedure, facilitating the detailed arthroscopic examination, as reported in literature (Van Ryssen \& Van Bree, 1998; Arias et al., 2003; Beale et al., 2003; Melo et al., 2003; Rezende et al., 2006, Borges, 2006).

\begin{tabular}{|c|c|c|c|c|}
\hline Structure & Region & Alteration & Wilcoxon & P-value \\
\hline $\begin{array}{l}\text { Synovial } \\
\text { membrane }\end{array}$ & $\begin{array}{l}\text { Lateral and medial } \\
\text { compartments, } \\
\text { suprapatellar region, } \\
\text { and insertion of the } \\
\text { patellar ligament } \\
\text { and tendon }\end{array}$ & $\begin{array}{l}\text { Villi } \\
\text { Vascularization } \\
\text { Fibrous cord }\end{array}$ & $\begin{array}{l}136.0 \\
120.0\end{array}$ & $\begin{array}{l}0.000 \\
0.001 \\
\text { No variability }^{1}\end{array}$ \\
\hline
\end{tabular}

\begin{tabular}{|c|c|c|c|c|}
\hline $\begin{array}{l}\text { Articular } \\
\text { cartilage }\end{array}$ & Patella & $\begin{array}{l}\text { Erosion } \\
\text { Fibrillation } \\
\text { Vascularization }\end{array}$ & $\begin{array}{l}10.00 \\
1.00\end{array}$ & $\begin{array}{l}\text { No variability }{ }^{1} \\
0.100 \\
1.000\end{array}$ \\
\hline
\end{tabular}




\begin{tabular}{|c|c|c|c|c|}
\hline Structure & Region & Alteration & Wilcoxon & P-value \\
\hline $\begin{array}{l}\text { Patellar } \\
\text { pouch }\end{array}$ & & $\begin{array}{l}\text { Erosion } \\
\text { Fibrillation } \\
\text { Vascularization }\end{array}$ & $\begin{array}{l}10.00 \\
45.00\end{array}$ & $\begin{array}{l}\text { No variability }^{1} \\
0.100 \\
0.009\end{array}$ \\
\hline Trochlea & & $\begin{array}{l}\text { Erosion } \\
\text { Fibrillation } \\
\text { Vascularization }\end{array}$ & $\begin{array}{l}6.00 \\
3.00\end{array}$ & $\begin{array}{l}\text { No variability }{ }^{1} \\
0.181 \\
0.371\end{array}$ \\
\hline $\begin{array}{l}\text { Intercondy- } \\
\text { lar fossa }\end{array}$ & & $\begin{array}{l}\text { Erosion } \\
\text { Fibrillation } \\
\text { Vascularization }\end{array}$ & $\begin{array}{l}3.00 \\
10.00\end{array}$ & $\begin{array}{l}\text { No variability }{ }^{1} \\
0.371 \\
0.100\end{array}$ \\
\hline $\begin{array}{l}\text { Lateral } \\
\text { femoral } \\
\text { condyle }\end{array}$ & & $\begin{array}{l}\text { Erosion } \\
\text { Fibrillation } \\
\text { Vascularization }\end{array}$ & $\begin{array}{l}55.00 \\
36.00\end{array}$ & $\begin{array}{l}\text { No variability }{ }^{1} \\
0.006 \\
0.014\end{array}$ \\
\hline $\begin{array}{l}\text { Medial } \\
\text { femoral } \\
\text { condyle }\end{array}$ & & $\begin{array}{l}\text { Erosion } \\
\text { Fibrillation } \\
\text { Vascularization }\end{array}$ & $\begin{array}{l}21.00 \\
21.00\end{array}$ & $\begin{array}{l}\text { No variability }{ }^{1} \\
0.036 \\
0.036\end{array}$ \\
\hline Tibia & & $\begin{array}{l}\text { Erosion } \\
\text { Fibrillation } \\
\text { Vascularization }\end{array}$ & & $\begin{array}{l}\text { No variability }{ }^{1} \\
\text { No variability }^{2}\end{array}$ \\
\hline $\begin{array}{l}\text { Lateral } \\
\text { trochlear } \\
\text { ridge }\end{array}$ & & $\begin{array}{l}\text { Erosion } \\
\text { Fibrillation } \\
\text { Vascularization }\end{array}$ & $\begin{array}{l}10.00 \\
1.000\end{array}$ & $\begin{array}{l}\text { No variability }{ }^{1} \\
0.100 \\
1.000\end{array}$ \\
\hline $\begin{array}{l}\text { Medial } \\
\text { trochlear } \\
\text { ridge }\end{array}$ & & $\begin{array}{l}\text { Erosion } \\
\text { Fibrillation } \\
\text { Vascularization }\end{array}$ & $\begin{array}{l}6.00 \\
1.00\end{array}$ & $\begin{array}{l}\text { No variability }{ }^{1} \\
0.181 \\
1.000\end{array}$ \\
\hline $\begin{array}{l}\text { Medial } \\
\text { meniscus }\end{array}$ & & & 10.00 & 0.100 \\
\hline $\begin{array}{l}\text { Lateral } \\
\text { meniscus }\end{array}$ & & & & No variability 1 \\
\hline $\begin{array}{l}\text { Cranial } \\
\text { cruciate } \\
\text { ligament }\end{array}$ & & Vascularization & 10.00 & 0.100 \\
\hline
\end{tabular}




\begin{tabular}{|c|c|c|c|c|}
\hline Structure & Region & Alteration & Wilcoxon & P-value \\
\hline $\begin{array}{l}\text { Caudal } \\
\text { cruciate } \\
\text { ligament }\end{array}$ & & Vascularization & 6.00 & 0.181 \\
\hline $\begin{array}{l}\text { Long digital } \\
\text { extensor } \\
\text { tendon }\end{array}$ & & $\begin{array}{l}\text { Neovasculariza- } \\
\text { tion } \\
\text { Villi }\end{array}$ & 6.00 & $\begin{array}{l}0.181 \\
\text { No variability } 3\end{array}$ \\
\hline
\end{tabular}

${ }^{1}$ All the evaluated differences were equal to 0 , thus no lesion was observed on Days 0 and 21.

${ }^{2}$ All the evaluated differences were equal to 0 , thus no lesion was observed on Days 0 and 21, except one dog, which already presented lesion before the rupture that persisted after the 21-day period.

${ }^{3}$ All the evaluated differences were equal to 0 , thus no lesion was observed on Days 0 and 21, except one dog, which already presented lesion before the rupture that persisted after the 21-day period.

Table 3. Wilcoxon test for the different lesions, observed between Days 0 and 21, at the stifle joint of dogs submitted to arthroscope-guided section of the cranial cruciate ligament (CrCL).

\begin{tabular}{|c|c|c|c|}
\hline Structure & Region & Wilcoxon & P-value \\
\hline \multirow{9}{*}{ Articular cartilage } & Patella & 1.00 & 0.500 \\
\hline & Suprapatellar pouch & 10.00 & 0.050 \\
\hline & Trochlea & No variability ${ }^{1}$ & \multirow{5}{*}{1.000} \\
\hline & Intercondylar fossa & No variability ${ }^{1}$ & \\
\hline & $\begin{array}{l}\text { Lateral femoral } \\
\text { condyle }\end{array}$ & 1.00 & \\
\hline & $\begin{array}{l}\text { Medialfemoral } \\
\text { condyle }\end{array}$ & No variability 1 & \\
\hline & Tibia & No variability $^{1}$ & \\
\hline & \multirow{2}{*}{\multicolumn{2}{|c|}{$\begin{array}{l}\text { Lateral trochlear ridge } 45.00 \\
\text { Medial trochlear ridge } 13.00\end{array}$}} & 0.005 \\
\hline & & & 0.089 \\
\hline
\end{tabular}

${ }^{1}$ All the observed differences were equal to 0 , thus no lesion was observed on Days 0 and 21.

Table 4. Wilcoxon test for osteophyte presence, observed on Days 0 and 21, at the stifle joint of dogs submitted to arthroscope-guided section of the cranial cruciate ligament (CrCL).

\begin{tabular}{cccccccccc}
\hline Dog & 1 & 2 & 3 & 4 & 5 & 6 & 7 & 8 & 9 \\
Wilcoxon & 120 & 3 & 113 & 15 & 105 & 66 & 66 & 21 & 21 \\
P-value & 0.001 & 0.371 & 0.003 & 0.059 & 0.001 & 0.004 & 0.004 & 0.036 & 0.036 \\
Dog & 10 & 11 & 12 & 13 & 14 & 15 & 16 & 17 & 18 \\
Wilcoxon & 28 & 21 & 91 & 91 & 105 & 66 & 10 & 15 & 55 \\
P-value & 0.022 & 0.036 & 0.002 & 0.002 & 0.001 & 0.004 & 0.100 & 0.059 & 0.006 \\
\hline
\end{tabular}

Table 5. Individual analysis of the intra-articular lesions of dogs, evaluated on Days 0 and 21, after arthroscope-guided section of the cranial cruciate ligament (CrCL). 
It was possible to precisely evaluate the menisci, the intermeniscal ligament, the synovial membrane, the articular cartilage, the cruciate ligaments, and the long digital extensor tendon by arthroscopy, as described in the literature (Van Ryssen \& Van Bree, 1998; Adamiak, 2002; Beale et al., 2003; Borges, 2006). The precision offered by the arthroscopic examination is reported by distinct authors (Sams, 2000; Adamiak, 2002; Arias et al., 2003; Beale et al., 2003; Melo et al., 2003; Rezende et al., 2006; Beale \& Hulse, 2010). Subcutaneous infiltration of liquid was not observed. Depending on the intensity of infiltration, capsule distension is impaired, and the examination becomes unviable (Van Ryssen et al., 1993). The arthroscopy showed itself as an effective method for evaluating the degenerative alterations after experimental CrCL section. According to Lipowitz et al. (1985) and Lewis et al. (1987), the $\mathrm{CrCL}$ section is accepted as the best model for the experimental induction of degenerative lesions. This result was observed in this study, with the additional advantage of direct visualization and magnification of image by arthroscopy, which allowed the evaluation of joint instability, as already reported by others (Lipowitz et al., 1985; Johnson \& Johnson, 1993; Glyde et al., 2002; Hulse et al., 2010; Bleedorn et al., 2011). According to Arnoczcky \& Marshall (1977), the degenerative process begins one week after CrCL rupture; thus, the articular evaluation on Day 21 is able to identify macroscopic lesions precociously, as observed in this study.

Signs of articular degeneration and inflammation could be noticed at the arthroscopic examination. According to Bennett \& May (1997) and Vaughan-Scott \& Taylor (1997), the unavoidable DJD progression can be mostly attributed to the enzymatic degradation of the articular cartilage.

For each dog, 14 areas or structures were evaluated by arthroscopy, in a total of 504 individual evaluations. On the day of the CrCL section, 17 dogs $(94.4 \%)$ presented shining and smooth surfaces of femur and patella, without periarticular osteophytes (Fig. 1.1). Only in one animal (5.6\%), irregularities at the trochlear ridge were detected.

From 18 evaluated joints, eight $(44.4 \%)$ had villous proliferation of thin and filamentous types (Fig. 1.2), considered normal according to McIlwraith \& Fessler (1978) and Lewis et al. (1987). In one animal, these villi were hyperemic, and, in nine, the synovial membrane was smooth, without villi. In all the cases, the villi were located at the medial compartment. McIlwraith \& Fessler (1978) reported that, in normal articulations, the thin, filamentous, and polyp-shaped villi are commonly observed in equines. Similar findings were reported in dogs (Lewis et al., 1987). Joint with normal villi, but with evident hyperemia suggests inflammatory process, and once the villous type is considered normal, it is possible to infer that the process is at an initial phase.

Discrete hyperemia of the synovial membrane was observed in 17 (94.4\%) dogs on Day 0 (Fig. 1.3), during the procedure that lasted 15 minutes on average. Due to the absence of dense fibrous tissue in the synovial membrane, increased local irrigation with congestion and swelling can develop during prolonged arthroscopic procedure (Lewis et al., 1987; Kurosaka et al., 1991), what may explain the findings of this work, not being, necessarily, synovial inflammation. In 14 dogs, the presence of blood vessels (Fig. 1.4) was observed along the CrCL. Despite these alterations in vascularization, the $\mathrm{CrCL}$ was intact and shining on Day 0, as well as the caudal cruciate ligament, the meniscofemoral ligament (Fig.1.5), and the long digital extensor tendon (Fig. 1.6). The origin of the popliteus muscle tendon was visualized in two animals (Fig. 1.7), and presented no alteration. 

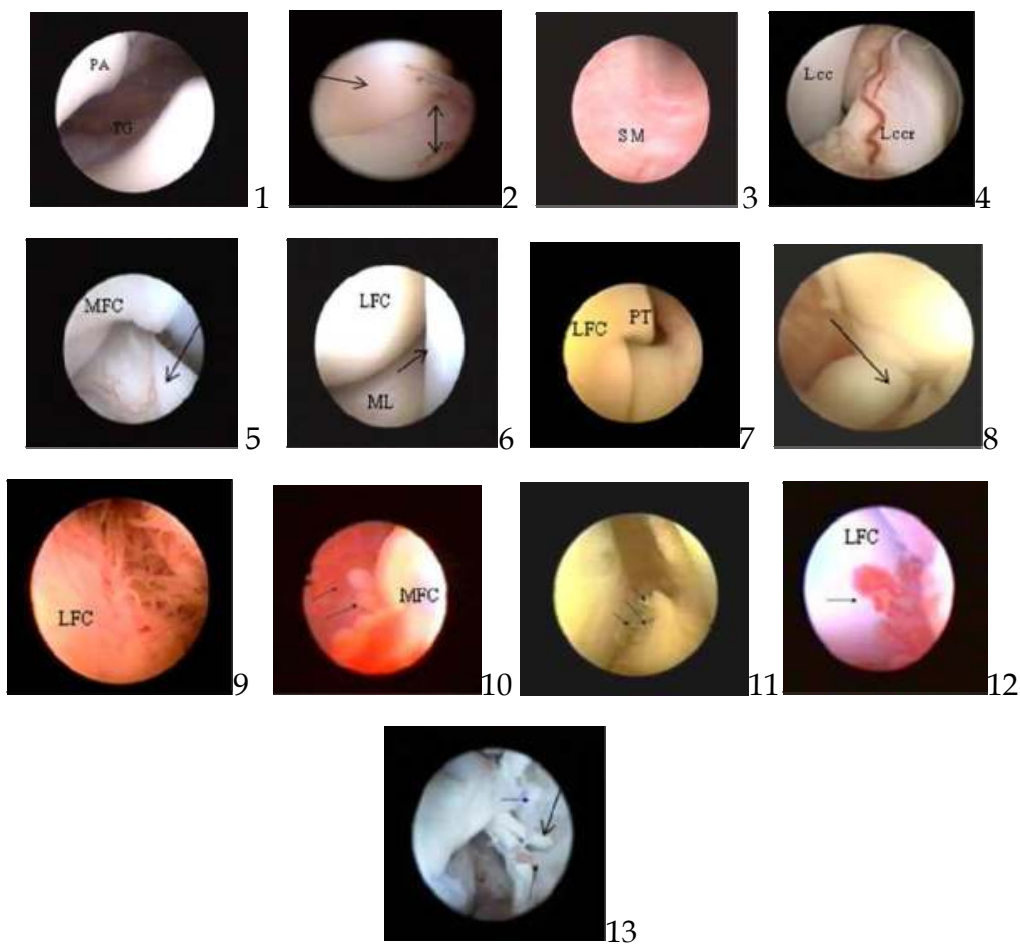

Fig. 1. Arthroscopic images of the stifle joint of dogs submitted to experimental section of the cranial cruciate ligament (Days 0 and 21) guided by arthroscopy. 1) Articular surfaces of the patella (PA) and trochlea (TC) of the femur without alterations; 2) Synovial membrane of the lateral compartment with filamentous villi ( arrow), lateral condyle of the femur ( arrow); 3) Synovial membrane (MS) with discrete hyperemia at the medial compartment; 4) Blood vessel along of the cranial cruciate ligament ( $\mathrm{LCCr}$ ), caudal cruciate ligament( $\mathrm{LCCd}$ ); 5) Meniscofemoral ligament (arrow); 6) Lateral compartment showing the lateral femoral condyle (LFC), long digital extensor tendon (arrow) and lateral meniscus (LM) 7) Origin of the popliteus muscle tendon(PT); 8) Intercondylar fossa with thin villi, stump of the cranial cruciate ligament showing nodular formation on the end of the torn ligament (arrow); 9) Villi in the shape of filamentous at the lateral compartiment; 10) Villi in the shape of polyp (arrows) at the medial compartment, medial femoral condyle (MFC); 11) Villus in the shape of fringe(arrows), lateral femoral condyle (LFC); 12) Villus in the shape of fan (arrow), lateral femoral condyle (CLF); 13) Lateral compartment showing villi in the shape of staff (arrow).

On Day 21 after CrCL section, at the arthroscopic examination, alterations suggesting articular degenerative process came to evidence. The arthroscopy, as mentioned by Adamiak (2002), is effective in precisely diagnosing the CrCL rupture and evaluating the evolution of the degenerative lesions of the joint, fact that was verified in this study. 
At the arthroscopic examination, in all animals, nodular formation on the end of the torn ligament were observed in the remaining stump of the CrCL on Day 21 (Fig. 1.8). In all animals, villous proliferation and synovial membrane hyperemia were observed, suggesting synovitis. As already reported by Van Ryssen \& Van Bree (1998), Sams (2000), Adamiak (2002), and Beale \& Hulse ( 2010), arthroscopy is an ideal diagnostic mean for evaluating macroscopically the synovial membrane, since the villi are kept in suspension in the irrigation liquid and, thus, projected into the cavity. Different types of villi, as well as different grades of hyperemia and vascularization were identified in detail (Table 1). Increase in the quantity of villi and new shapes were verified. Also, villous proliferations in all articular compartments were evidenced, suggesting DJD, as described in literature (Lewis et al., 1987; Kurosaka et al., 1991; Beale et al, 2003; Borges, 2006). Filamentous and thin (Fig 1.9), short, interlaced, as well as in the shape of polyp (Fig. 1.10), fringe (Fig. 1.11), fan (Fig. 1.12), staff (Fig. 1.13), short, membranous and staff(Fig. 2.1) and cauliflower villi were identified. In $21.8 \%$ of the joints, there were only short, thin, and filamentous villi, characterizing discrete synovitis. These three types of villi were found in bigger quantity and in all joints. In $55.5 \%$ of the animals, associated to the already mentioned villi, there were also those in the shape of bush, fan, polyp, and interlaced, characterizing moderate synovitis. In $22.7 \%$, villi in the shape of fringe and cauliflower were also found, characterizing severe synovitis. Such characteristics of the synovial membrane are associated to DJD. In humans, the arthroscopic examination of the synovial membrane is employed for characterizing and diagnosing different types of pathological articular processes, as, for instance, traumatic, suppurative, tubercular, and rheumatoid arthritis (Kurosaka et al., 1991). At the insertion of the long digital extensor tendon, neovascularization was noticed in three animals (Fig. 2.2), while, in two, thin and apparently normal-colored villi (Fig. 2.3) were seen. Fibrillation in the articular cartilage and absence of erosion in the articular surfaces were verified in all evaluated animals. Fibrillation, according to Johnston (1997), is the initial microscopic finding of DJD. It may be observed as soon as one week after CrCL rupture (Johnson and Johnson, 1993), while erosive lesions are late findings, which occur with, at least, 60 days of joint instability. Statistically, fibrillation was predominant (Table 3) at the medial and lateral condyles (Fig. 2.4). Areas of fibrillation at the articular surface of the patella, the trochlear ridges of the femur, and the intercondylar fossa were also observed (Fig. 2.5). Fibrillation of the articular surface was arthroscopically evidenced as filaments from the cartilage into the articular space. In arthroscopy, the visualization of fibrillation is possible due to the amplified image and the liquid environment. By arthrotomy, it is only possible to detect areas that are apparently thickened, rugose, and opaque, corresponding to fibrillation (Sams, 2000; Adamiak, 2002). There was also fibrin at the lateral (66.\%) and medial (34\%) compartments (Fig. 2.6 and 2.7, respectively), and at the suprapatellar pouch (27.7\%; Fig. 2.8), as well as osteophytes at the trochlear ridges, distal extremity of the patella, and suprapatellar pouch. Osteophytosis was statistically significant (Table 4) at the lateral trochlear ridge (Fig. 2.9). Muzzi (2003) detected radiographically the formation of osteophytes with, at least, 30 days of $\mathrm{CrCL}$ rupture. The arthroscopic findings concerning the presence of osteophytes, 21 days after articular destabilization were similar to those reported by Lewis et al. (1987). The presence of periarticular osteophytes is one of the signs of DJD (Elkins et al., 1991; Moore \& Read, 1996). Thirteen animals presented vascularization of the articular cartilage, evidenced at the 
insertion of the patellar ligament and quadriceps tendon (Fig. 2.10 and 2.11), at the suprapatellar pouch towards the trochlea (Fig. 2.12), at the femoral condyles (2.13), and at the intercondylar fossa towards the condyles. This was statistically significant for the region of the femoral condyles. Such a finding corresponds not to the cartilage vascularization itself, but to the synovial membrane vascularization that invades the cartilage.
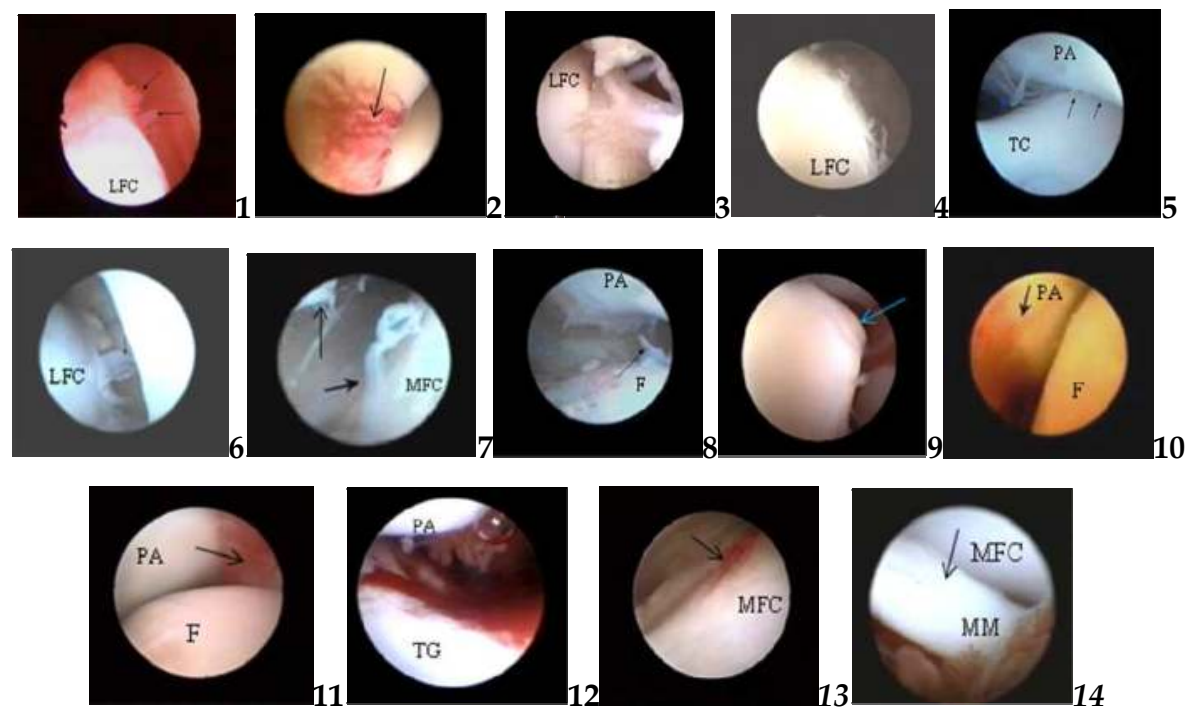

Fig. 2. Arthroscopic images of the stifle joint of dogs submitted to experimental section of the cranial cruciate ligament (Days 0 and 21) guided by arthroscopy. 1) Lateral compartment showing villi short, membranous and in the shape of staff (arrows); 2) Visualization of the long digital extensor tendon, vascularization (arrow), 3) Thin villi at the long digital extensor tendon (arrow), lateral femoral condyle (LFC), 4) Fibrillation at the lateral femoral condyle (LFC); 5) Fibrillation (arrows) and fibrin at the surface of the patella (PA), proximal trochlear groove (TC); 6) Fibrin attached to the lateral femoral condyle (LFC) (arrows); 7) Fibrin at the medial femoral condyle (arrow) and patella; 8) Supratellar pouch with vascularization and fibrin (arrow); 9) Lateral femoral condyle (LFC) with mild osteophytes (irregularities: arrow); 10) Vascularization at the insertion of the patellar ligament (arrow); 11) patellar tendon (arrow); 12) suprapatellar pouch 13); and at the medial trochlear ridge of the femoral condyle (arrow) 14) Prolapse of the caudal horn of the medial meniscus (MM).

Statistically, the results regarding the lesion in the menisci were not significant; nevertheless, prolapse of the caudal horn of medial meniscus (Fig. 2.14) was visualized in four animals $(22.2 \%)$. In one of them, on Day 0 , there were alterations compatible with synovitis, like hyperemia and increased synovial membrane villi. Three of them presented, on Day 21, meniscus lesion and periarticular irregularities. The medial meniscus is more susceptive to lesions due to its capsule fixation (Moore \& Read, 1996). It is reported that meniscus lesions occur about the seventh week of articular instability by CrCL rupture (Johnson \& Johnson, 1993). In this work, the precocious occurrence of this kind of lesion may 
be attributed to the eventual excited behavior of the patients. Concerning the DJD, the body mass of the animals, which ranged from 18 to $25 \mathrm{~kg}$, must also be considered for this study. According to Bennett et al. (1988), the CrCL rupture in dogs with body mass under $15 \mathrm{~kg}$ usually causes degenerative alterations that are less severe than in heavier dogs.

\section{Conclusions}

As a valuable instrument for macroscopic evaluation of articular tissues, arthroscopy is a safe method for diagnosing and following-up the alterations in the stifle joint of dogs. The technique allows tracking the evolution of the degenerative lesions, as well as classifying the synovitis according to the villi shape and synovial membrane hyperemia.

\section{References}

Adamiak, Z. (2002). Arthroscopy in dogs with cranial cruciate ligament injuries.Indian Vet. J. vol.79, nº 2, pp.177-178, ISSN 0019-6479

Arias, S.A., Rezende, C.M.F., Melo, E.G.,Nunes, V.A. \& Correa, J.C (2003). Radiological, arthroscopical evaluation and synovial membrane histology of the knee of dogs treated with chondroitin sulphate- sodium hialuronate association after experimental degenerative joint disease. Brasilian J. Vet. Res. Anim. Sci., vol.55, nº4, pp. 421-429, ISSN 0102-0935

Arnoczky, S.P. \& Marshall, J.L. (1977). The cruciate ligaments of the canine stifle: An anatomical and funcional analysis. Am. J. Vet. Res., vol.38, $\mathrm{n}^{\circ} 11, \mathrm{pp} .1807-1814$, ISSN 0002-9645

Beale, B. S., Hulse, D. A., Schulz, K. S.,Whitney, W. O. (2003). Arthroscopically assisted surgery of the stifle joint, In: Small Animal arthroscopy, 117-157, Saunders, ISBN 07216-8969-8, Philadelphia, Pennsylvania

Beale, B. S. \& Hulse, D. A.(2010). Arthroscopy versus arthrotomy for surgical treatment, In: Advances in the canine cranial cruciate ligament, P. Muir,(Ed.), 145-158, WileyBlackwell, ISBN 978-0-8138-1852-8, Ames, Iowa

Bennett, D. \& May, C. (1997). Joint diseases of dogs and cats. In: Textbook of Veterinary Internal Medicine. 4.ed., S.J. Ettinger \& E.C. Feldman (Eds.), pp. 2032-2077, Saunders, ISBN 0721634273, Philadelphia, Pensylvania.

Bennett, D. Tennant, B. Lewis, D.G. Baughan, J. May, C. \& Carter, S. (1988). A re-appraisal of anterior cruciate ligament disease in the dog. J. Small Anim. Pract., vol. 29, no5, pp.275-297, ISSN 0022-4510

Bleedorn, J. A, Greuel, E. N., Manley, P. A., Schaefer, S. L., Markel, M. D., Holzman, G., Muir, P. (2011). Synovitis in dogs with stable stifle joints and incipient cranial cruciate ligament rupture: a cross-sectional study. Vet. Surg. vol 40, no 5, pp. 531543, ISSN 0161-3499

Borges, N.F. (2006).Videoarthroscopy of the femorotibiopatellar joint in dogs before and 21 daysafter cranial cruciate ligament rupture (experimental study). 40pp. Dissertation) Escola de Veterinária, Universidade Federal de Minas Gerais, Belo Horizonte, Brazil

Case, J. B., Hulse, D. Kerwin, S. C., Peycke, L. E. (2008). Meniscal injury following initialcranial cruciate ligament stabilization surgery in 26 dogs ( 29 stifles). Vet. Comp.Orthop. Traumatol., vol. 21, $\mathrm{n}^{\circ}$ 4, pp. 365-367, ISSN 0932-0814 
Cook, J. L. ( 2010). Cranial cruciate ligament disease in dogs: biology versus biomechanics.Vet. Surg. vol. 39, no 3, pp. 270-277, ISSN 0161-3499

de Rooster, H., de Bruin,T., Van Bree, H. (2010). Morphology and function of the cruciate ligaments, In: Advances in the canine cranial cruciate ligament, P. Muir,(Ed.), 5-12, WileyBlackwell, ISBN 978-0-8138-1852-8, Ames, Iowa

Elkins, A.D., Pechman, R. \& Kearney, M.T. (1991). A retrospective study evaluating the degree of degenerative joint disease in the stifle joint of dogs following surgical repair of anterior cruciate ligament rupture. J. Am. Anim. Hosp. Assoc., vol.27, September/October, pp.533-540, ISSN 0587-2871

Frizziero,L. \& Ronchetti, I.P.(2002). Intra-articular treatment of osteoarthritis of the knee: an Anthroscopic and clinical comparison between sodium hyaluronate (500-730 kDa) and methilprednisolone acetate. J.Orthopaed. Traumatol., vol. 3, n², pp.89-96, ISSN 1590-9921

Glyde, M.R. Wong, W.T., Lidbetter, D. Parry, B. \& Middleton, D. (2002). Partial rupture of the cranial cruciate ligament in 13 dogs: Clinical, radiological, clinicopathological and histhopathological features. Ir. Vet. J., vol. 55, n6, pp. 271-276, ISSN 0368-0762

Goldhammer,M.A., Smith, S. H., Fitzpatrick, N., Clements, D. N. (2010). A comparison of radiographic, arthroscopic and histological measures of articular pathology in the canine elbow joint. The Vet. Journal, vol.186, nº 1, pp. 96-103, ISSN 1090-0233

Hulse, D., Beale, B., Kerwin, S. ( 2010). Second look arthroscopic findings after tibial plateauLeveling osteotomy. Vet. Surg. vol. 39, no 3, pp. 350-354, ISSN 0161-3499

Innes, J. F., Costello ,M., Barr, F. J., Rudorf, H., Barry, A. R. S.(2004). Vet. Radiol. Ultrasound,vol. 45, no 2, pp.143-148, ISSN 1058-8183

Innes, J. F.(2010). Progression of arthritis after stifle stabilization, In: Advances in the caninecranial cruciate ligament, P. Muir,(Ed.), 229-232, Wiley-Blackwell, ISBN 978-08138 -1852-8, Ames, Iowa

Johnson, J.M. \& Johnson, A.L. (1993). Cranial cruciate ligament rupture: pathogenesis, diagnosis, and postoperative rehabilitation. Vet. Clin. North Am.: Small Anim. Pract., vol.23 nº, pp.717-733, ISSN 0195-5616

Johnston, A.S. (1997). Ostearthritis: joint anatomy, physiology and pathobiology. Vet. Clin. North. Am.:Small Anim. Pract., vol.27, n4, pp. 699-719, ISSN 0195-5616

Kurosaka, M., Ohno, O.\& Hirorat, A.K.( 1991). Arthroscopic evaluation of synovitis in the knee joints. Arthroscopy, vol.7, no 2, pp.162-170, ISSN 0749-8063

Lazar, T. P., Berry, C. R., de Haan, J. J., Peck,J. N. Correoa, M.(2005). Long-term radio-graphic comparison of tibial plateau leveling osteotomy versus extra-capsular stabilization for cranial cruciate ligament rupture in the dog. Vet. Surg., vol.34, nº 2, pp. 133-141, ISSN 0161-3499

Lewis, D.D.; Goring, R.L.; Parker, R.B. \& Curasi, P.A. (1987). A comparison of diagnostic methods used in the evaluation of early degenerative joint disease in the dog. J. Am. Anim. Hosp. Assoc., vol.23, May/June, pp. 305-315, ISSN 0587-2871

Lipowitz, A.J.; Wong, P.L.; Stevens, J.B. (1985). Synovial membrane changes after experimental transecction of the cranial cruciate ligament in dogs. Am. J. Vet. Res., vol. 46, $\mathrm{n}^{\circ} 5$, pp.1166-1170, ISSN 0002-9645

Ljungvall, K. \& Ronéus, B. (2011). Arthroscopic surgery of the middle carpal joint in trotting Standardbreds: findings and outcome. Vet. Comp. Orthop. Traumatol. , vol. 24, $\mathrm{N}^{\mathrm{o}}$ 5, PMID 21792476, DOI: 10.3415/VCOT-10-12-0161, ISSN 0932-0814 
McIlwraith, C.W.\& Fessler, J.F. (1978). Arthroscopy in the diagnosis of equine joint disease. J. Am. Vet. Med. Assoc., vol.172, no 3, p.263-268, ISSN 0003-1488

Melo, E.G., Rezende, C.M.F., Gomes, M.G., Freitas, P.M., Arias, S.A.S. (2003) .Chondroitin sulfate and sodium hialuronate in treatment of the degenerative joint disease in dogs. Clinical and radiological aspects. Brasilian J. Vet. Res. Anim. Sci. vol. 55, n ${ }^{\circ} 1$, pp.35-43, ISSN 0102-0935

Moore, K.W. \& Read, R.A. (1996). Rupture of the cranial cruciate ligament in dogs. Part I. Compend. Cont. Educ. Pract. Vet., vol.18, n³, p.223-234, ISSN 0193-1903

Muzzi, L.A.L. (2003). Physiotherapie and temporary immobilization after arthroscopic repair of the cranial cruciate ligament in dogs. 79pp. (Thesis) - Escola de Veterinária, Universidade Federal de Minas Gerais, Belo Horizonte, Brazil

Person, M.W. (1985). A procedure for arthroscopic examination of the canine stifle joint. J. Am. Anim. Hosp. Assoc., vol.21, March/ April, pp.179-186, ISSN 0587-2871

Pozzi, A. \& Kim, S. E.(2010). Biomechanics of the normal and cranial cruciate ligamentdeficient stifle, In: Advances in the canine cranial cruciate ligament, P. Muir,(Ed.), 3742, Wiley-Blackwell, ISBN 978-0-8138-1852-8, Ames, Iowa

Rezende, C.M.F., Melo, E.G., Madureira, N.G., Freitas, P. M. (2006). Arthroscopy of the stifle joint in dogs. Brasilian J.Vet.Res.Anim. Sci. vol. 58, no 5, pp. 841-848, ISSN 0102-0935

Rochat, M.C. Arthroscopy. (2001).Vet. Clin. North. Am.:Small Anim. Pract., vol.31, pp.761-787, ISSN 0195-5616

Sams, A.E. (2000). Canine elbow joint arthroscopy: introduction and description of technique. Comp. cont. Educ. Pract.Vet. vol. 22. n 2, pp.135-144, ISSN 0193-1903

Schrader, S.C. (1995). Joint diseases of the dog and cat. In: Small animal orthopedics, M.L. Olmstead, (Ed.), pp.437-471, Mosby, ISBN 0-8016-5874-8, St. Louis, Missouri

Siemering, G.B. \& Eilert, R.E. (1986). Arthroscopy study of cranial cruciate ligament and medial meniscal lesions in the dog. Vet. Surg. vol.15, $\mathrm{n}^{\circ} 3$,pp.265-269, ISSN 01613499

Van Bree, H., de Rooster, H., Gielen, I. (2010). Stress radiography of the stifle,In: Advances in the canine cranial cruciate ligament, P. Muir,(Ed.), 113-116,Wiley-Blackwell, ISBN 9780-8138-1852-8, Ames, Iowa

Van Ryssen, B., Van Bree, H. \& Missinne, S. (1993).Successfull arthroscopy treatment of shoulder osteochondrosis in the dog. J. Small Anim. Pract., vol.34, $\mathrm{n}^{\mathrm{o}}$ 10, pp.521-528, ISSN 0022-4510

Van Ryssen, B. \& Van Bree, H. (1998). Diagnostic and surgical arthroscopy in small animals, In: Canine Sports Medicine and Surgery, M.S. Bloomberg, J.F.Dee \& R. A.Taylor,(Eds.), pp.250-254, Saunders, ISBN 0-7216-5022-8, Philadelphia, Pennsylvania

Vasseur, P. B. \& Berry, C. R.(1992). Progression of stifle osteoarthrosis followingreconstruction of the cranial cruciate ligament in 21 dogs. J. Am. Anim. Hosp.Assoc., vol. 28, March/april, pp.129-136, ISSN 0587-2871

Vaughan-Scott, T. \& Taylor, J.H. (1997).The pathophysiology and medical management of canine osteoarthrtitis. J. S. Afr. Vet. Assoc., vol.68, no 1, pp.21-25,ISSN 0038-2809 


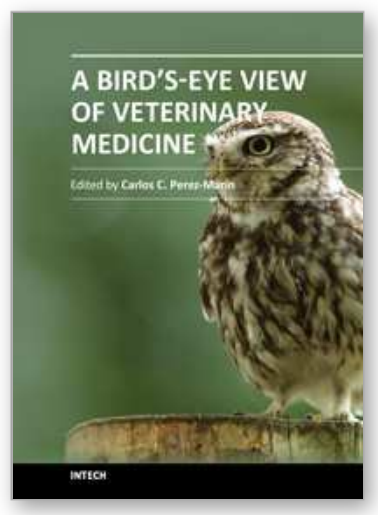

\author{
A Bird's-Eye View of Veterinary Medicine \\ Edited by Dr. Carlos C. Perez-Marin
}

ISBN 978-953-51-0031-7

Hard cover, 626 pages

Publisher InTech

Published online 22, February, 2012

Published in print edition February, 2012

Veterinary medicine is advancing at a very rapid pace, particularly given the breadth of the discipline. This book examines new developments covering a wide range of issues from health and welfare in livestock, pets, and wild animals to public health supervision and biomedical research. As well as containing reviews offering fresh insight into specific issues, this book includes a selection of scientific articles which help to chart the advance of this science. The book is divided into several sections. The opening chapters cover the veterinary profession and veterinary science in general, while later chapters look at specific aspects of applied veterinary medicine in pets and in livestock. Finally, research papers are grouped by specialisms with a view to exploring progress in areas such as organ transplantation, therapeutic use of natural substances, and the use of new diagnostic techniques for disease control. This book was produced during World Veterinary Year 2011, which marked the 250th anniversary of the veterinary profession. It provides a fittingly concise and enjoyable overview of the whole science of veterinary medicine.

\title{
How to reference
}

In order to correctly reference this scholarly work, feel free to copy and paste the following:

Cleuza Maria de Faria Rezende, Eliane Gonçalves de Melo and Natalie Ferreira Borges (2012). Arthroscopic Follow-Up After Rupture of the Cranial Cruciateligament, A Bird's-Eye View of Veterinary Medicine, Dr. Carlos C. Perez-Marin (Ed.), ISBN: 978-953-51-0031-7, InTech, Available from: http://www.intechopen.com/books/abird-s-eye-view-of-veterinary-medicine/arthroscopic-follow-up-after-rupture-of-the-cranial-cruciate-ligament

\section{INTECH}

open science | open minds

\section{InTech Europe}

University Campus STeP Ri

Slavka Krautzeka 83/A

51000 Rijeka, Croatia

Phone: +385 (51) 770447

Fax: +385 (51) 686166

www.intechopen.com

\section{InTech China}

Unit 405, Office Block, Hotel Equatorial Shanghai

No.65, Yan An Road (West), Shanghai, 200040, China

中国上海市延安西路65号上海国际贵都大饭店办公楼 405 单元

Phone: +86-21-62489820

Fax: $+86-21-62489821$ 
(C) 2012 The Author(s). Licensee IntechOpen. This is an open access article distributed under the terms of the Creative Commons Attribution 3.0 License, which permits unrestricted use, distribution, and reproduction in any medium, provided the original work is properly cited. 